\title{
Simplification of a haemolytic micromethod for toxic saponin quantification in alfalfa
}

\author{
PIOTR M. GÓRSKI and MARIAN JURZYSTA \\ Department of Biochemistry and Plant Physiology, \\ Institute of Soil Science and Plant Cultivation, \\ 24-100 Puławy, Poland
}

(Received: November 18, 1986)

\begin{abstract}
A simplification of a haemolytic micromethod is presented. In the orginal method, alfalfa (Medicago media Pers.) leaf sap is spotted on the plate covered with a blood-gelatine suspension. In the presented method, the mashed alfalfa pulp is used instead of sap. Due to saponin diffusion and the reaction with erythrocytes, a haemolytic ring appears, which has a width proportional to the concentration of toxic saponins. It is shown that the width of haemolytic ring does not depend on the sample weight ranging from 20 to $100 \mathrm{mg}$. This allows for the omission of laborious sap pressing and sample quantification. Individual alfalfa plants with different saponin contents were tested using leaf sap and leaf pulp for analyses. Good agreement was found with sap and leaf pulp methods. The correlation obtained by both methods was high, $r=0.87$. The modified method requires only a small amount of plant material and makes the analyses of large numbers of individual plants per day possible. The method is especially recommended for breeding purposes.
\end{abstract}

\section{INTRODUCTION}

Alfalfa contains pentacyclic triterpenes - saponins. A group of these compounds - medicagenic acid glycosides - shows fungistatic, haemolytic and allelopathic properties. This group of saponins is also toxic to fish, causes a decrease of growth of young monogastric animals and reduces egg production in hens (Birk, 1969; Checke, 1971; Gestetner et al., 1971). Because of these antinutritional properties, a simple and rapid method of toxic saponin quantification for alfalfa is needed. In 1979 Jurzysta reported a rapid haemolytic method of saponin quantification. The method employs sap taken from alfalfa leaves, which is then spotted on plate covered with blood in gelatine. Because of the haemolytic action of saponins, a haemolytic ring appears around the droplet. The width of that ring is proportional to the saponin content in sap. 
We, as well as some other breeders, have been using that method intensively with good results for several years. But to obtain the sap, a special small press is needed, and the obtained sap must be quantified with a microsyringe. The sap-pressing procedure is the most laborous and time consuming part of the work. We are presenting a modification of the haemolytic method in which mashed alfalfa leaf pulp is used instead of sap.

\section{MATERIAL AND METHODS}

Sample preparation: Plant sap was obtained from alfalfa leaves with a small press. Ten microliters were spotted on the blood-gelatine plate as previously described (Jurzysta 1979). Leaf pulp was obtained from one to a few alfalfa leaves by grinding them in small porcelain vessels with a glass rod, or in $1.5 \mathrm{ml}$ plastic dispensable centrifuge tubes with a cone-shaped pestle. Larger samples were ground with a mortar and pestle. Standard curves. For saponin determination in leaf sap about $0.5 \mathrm{~kg}$ of fresh clover leaves were ground and juice filtered through a G-3 filter under reduced pressure. This juice was used for preparing standards containing $0.04-0.20 \%$ of alfalfa saponins. Standard saponins were obtained from alfalfa leaves according to Jurzysta et al., 1984. For saponin determination in leaf pulp about $20 \mathrm{~g}$ of fresh clover leaves were ground in a mortar. The obtained pulp and standard saponins were used to prepare concentrations of $0.04-0.20 \%$ (Fig. 1).

Preparation of plates and determination of saponins. Glass plates were covered with a $0.25 \mathrm{~mm}$ layer of blood suspended in gelatine (J u r z y s ta, 1979). Ten $\mu l$ drops of leaf sap were placed on these plates using a microsiringe. Portions of leaf pulp were placed on the plates with a spatula. Each portion

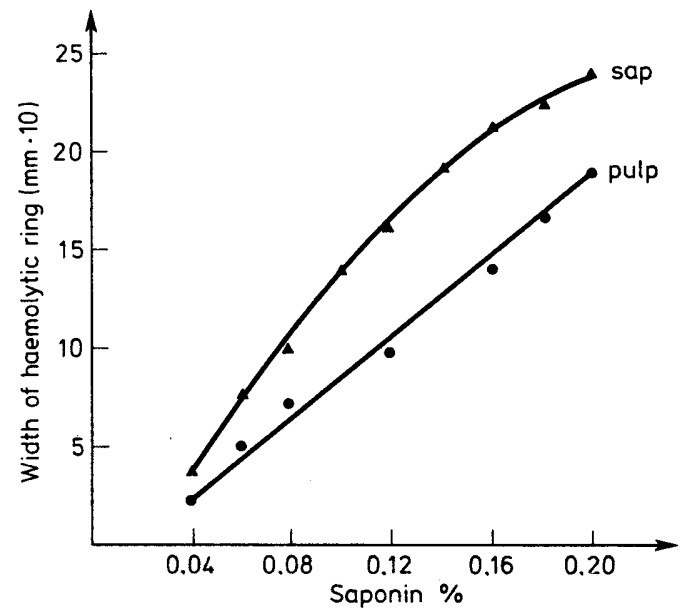

Fig. 1. Standard curves for quantitative analyses of toxic saponins in leaf sap (triangles) and leaf pulp (dots) of alfalfa 
was weighed together with a spatula before spotting. Large portions of pulp were placed on the plates in the same way but always forming rows $1 \times 0.2 \mathrm{~cm}$. The plates were then horizontally positioned in a multiplate TLC chamber (chromatographic tank). After $20 \mathrm{~h}$ the widths of the haemolytic rings were measured using a photographic enlarger at 10-fold magnification.

\section{RESULTS AND DISCUSSION}

After using the haemolytic micrometbod for several years, we noticed that the efficiency of the method depends mainly on the output of the plant press. To avoid sap production, in large screening preliminary tests, we used mashed alfalfa leaves instead of sap. Then we found that the width of the haemolytic ring did not depend on the quantity of leaf pulp spotted. Precise analyses of sample weight and of the width of the haemolytic ring showed that in the range of 20-100 mg, the width of the haemolytic ring was very stable (Fig. 2). Only when the amount of sample material was very small $(0-15 \mathrm{mg})$ did the width of the haemolytic ring vary. On contrast, large samples (over $100 \mathrm{mg}$ ) when placed in rows, produced somehow bigger but stable rings (Table 1).

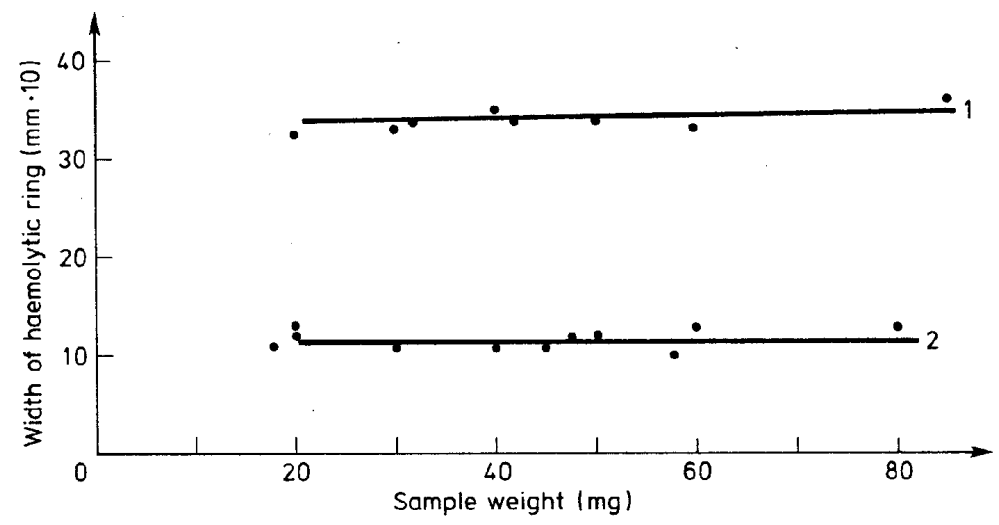

Fig. 2. Sample weight and width of haemolytic ring in high saponin (no. 1) and low saponin plant (no. 2)

To compare the new method (pulp) with the old one (sap) individual alfalfa plants were analysed. Statistical analyses of all obtained data indicates good correlation of both methods. A correlation of $r=0.87$ was found for samples weighing $20-100 \mathrm{mg}$ and $r=0.79$ for samples weighing more than $100 \mathrm{mg}$. The saponin content found in alfalfa plants with both methods was very similar (Table 1). In plants no. 2 and 3 no haemolytic rings were obtained. However, small rings were noted in the pulp analyses. This was probably due to some dissipation of the sap droplet, which had covered and masked smaller rings. Those phenomena do not occur when pulp is used. 
Table 1

Width of haemolytic ring and saponin content in alfalfa plants quantified in leaf sap and leaf pulp

\begin{tabular}{|c|c|c|c|c|c|c|}
\hline \multirow{2}{*}{ Plant } & \multirow{2}{*}{$\begin{array}{l}\text { No. and } \\
\text { No. }\end{array}$} & \multicolumn{3}{|c|}{$\begin{array}{l}\text { Width of haemolytic ring* } \\
(\mathrm{mm} \times 10)\end{array}$} & \multicolumn{2}{|c|}{ Saponin content $(\%)$} \\
\hline & & $\begin{array}{c}\text { sap } \\
10 \mu 1\end{array}$ & $\begin{array}{c}\text { pulp } \\
20-100 \\
\mathrm{mg}\end{array}$ & $\begin{array}{c}\text { pulp } \\
<100 \\
\text { mg }\end{array}$ & $\begin{array}{c}\text { in } \\
\text { sap }\end{array}$ & $\begin{array}{c}\text { in fr. weight } \\
\text { pulp } \\
20-100 \mathrm{mg}\end{array}$ \\
\hline 1. & $22-1$ & 0 & 0 & 0 & 0 & 0 \\
\hline 2. & $3-1$ & 0 & 1 & 2 & 0 & $>0.04$ \\
\hline 3. & $18-2$ & 0 & 3 & 6 & 0 & $>0.04$ \\
\hline 4. & $3-2$ & 5 & 2 & 5 & 0.04 & 0.04 \\
\hline 5. & $100-1$ & 13 & 16 & 17 & 0.11 & 0.17 \\
\hline 6. & $18-3$ & 15 & 11 & 14 & 0.11 & 0.12 \\
\hline 7. & $35-1$ & 23 & 12 & 21 & 0.19 & 0.13 \\
\hline 8. & $14-2$ & 21 & 15 & 20 & 0.15 & 0.16 \\
\hline 9. & $4-1$ & 23 & 34 & 40 & 0.19 & $<0.20$ \\
\hline 10. & $13-1$ & 26 & 15 & 20 & $<0.20$ & 0.16 \\
\hline 11. & $100-2$ & 25 & 25 & 35 & $<0.20$ & $<0.20$ \\
\hline 12. & $4-2$ & 26 & 35 & 40 & $<0.20$ & $<0.20$ \\
\hline & Mean & 14.8 & 13.8 & 15.7 & 0.12 & 0.13 \\
\hline
\end{tabular}

* Mean of 3 analyses.

The presented data show that the quantification of saponins using leaf pulp is faster and simpler than using leaf sap. Even without sample weighing the method is quantitative as long as an adequate sample is used. A larger samples are recommended as the spotting of a few replicates from each sample. The method is especially well-suited for breeding purposes since saponin-free as well as high-saponin plants can easily be analysed without error.

\section{REFERENCES}

Birk Y., 1969. Saponins: [In:] Toxic constituents of plant foodstuffs. I. E. Liener (ed.), Academic Press, New York, London.

Checke P. R., 1971. Nutritional and physiological implications of saponins. A review. Can. J. Anim. Sci. 51: 621-628.

Gestetner B., Shany S., Assa Y., 1971. Medicagenic acid, the factor responsible for haemolytic activity of lucerne saponins. Experientia 27: 40-43.

Jurzysta M., 1979. Haemolytic micromethod for rapid estimation of toxic alfalfa saponin. Acta Agrobot. 32: 5-11.

Jurzysta M., Oleszek H., Szymanek B., 1984. Medicagenic acid glycosides as a standard for determination of toxic saponins in alfalfa. Medicago Work. Group. Eucarpia, Brno, pp. 339-347. 


\section{Uproszczona hemolityczna mikrometoda szybkiego oznaczenia toksycznych saponin lucerny}

\section{Streszczenie}

W oryginalnej metodzie na pokrytą warstwą krwi w żelatynie płytkę nanosi się sok wyciśnięty $\mathrm{z}$ liści lucerny. Opracowana modyfikacja polega na użyciu homogenatu z roztartego liścia zamiast soku. W wyniku dyfuzji saponin i ich reakcji $\mathrm{z}$ czerwonymi ciałkami krwi powstają pierścienie hemolityczne, których szerokość jest proporcjonalna do zawartości saponin w próbce. Wykazano, że szerokość pierścienia hemolitycznego nie zależy od wielkości próbki w przedziale $20-100 \mathrm{mg}$. Pozwala to na pominięcie ilościowego nanoszenia, jak również nie jest konieczne pracochlonne wyciskanie soku, co bardzo przyspiesza i upraszcza analizy. Pojedyncze rośliny lucerny o zróżnicowanej zawartości saponin analizowano stosując sok i homogenat liściowy. Wykazano dobrą korelacje wyników uzyskanych obiema metodami $(r=0.87)$. Opisana metoda pozwala na wykonanie analiz z bardzo małej próbki i na przeprowadzenie bardzo dużej ilości analiz. Metoda przydatna jest zwłaszcza dla celów hodowlanych. 